\title{
SISTEM PENDUKUNG KEPUTUSAN UNTUK MENENTUKAN LOKASI USAHA KULINER YANG STRATEGIS MENGGUNAKAN METODE NAIVE BAYES
}

\author{
${ }^{1}$ Muiza Ulin Nuhayati, Dedih, Jajang Mulyana \\ STMIK Kharisma Karawang, Teknik Informatika \\ ${ }^{1}$ muizzaulinnuha@yahoo.co.id; ${ }^{2}$ dedih@stmik-kharisma.ac.id; ${ }^{3}$ za2nk@yahoo.com
}

\begin{abstract}
ABSTRAK
Decision Support System merupakan sebuah perangkat lunak yang dikembangkan secara khusus untuk membantu dalam proses pengambilan keputusan. Sistem pendukung keputusan untuk menentukan lokasi usaha kuliner yang strategis ini dipergunakan sebagai "second opinion" atau "information sources" yang dapat dipakai sebagai bahan pertimbangan sebelum seorang memutuskan untuk mengambil suatu keputusan ketika akan membuka suatu usaha di lokasi yang dipilih. Perancangan sistem ini menggunakan bahasa pemrograman PHP, Apache sebagai Web server dan MySQL sebagai DBMS (Database Management System). pengebangan sistem ini mengunakan SDLC Waterfall. Metode yang digunakan dalam decision support system ini adalah dengan menggunakan metode naive bayes yaitu memprediksi peluang yang akan terjadi kedepannya berdasarkan kejadian dimasa lampau. sehingga selain dapat menarik minat penggunanya, diharapkan sistem ini dapat merepresentasikan keadaan dunia nyata atau bisnis yang sebenarnya.
\end{abstract}

\begin{abstract}
Decision Support System is a software developed specifically to assist in the decision making process. Decision support system for determining the location of strategic culinary business is treated as a "second opinion" or "information sources" that can be used as a material consideration before deciding to take a decision when going to open a business in the selected location. The design of this system using the programming language PHP, Apache as the Web server and MySQL as DBMS (Database Management System). pengebangan this system using SDLC Waterfall. This meth od used in the decision support system is using Naive Bayes method that predicts the chance that will happen in the future based on past events. so that in addition to attracting users, this system is expected to represent the real-world situation or the actual business.
\end{abstract}

Keywords : Decision support system, Naive bayes

Jurnal Interkom Vol.1 No. 12 - April 2017 


\section{PENDAHULUAN}

\section{Latar Belakang}

Teknologi komputer dalam beberapa tahun terakhir ini mengalami perkembangan yang begitu pesat,hal ini berdampak pada persaingan dunia usaha yang semakin ketat, baik perusahaan yang bergerak di bidang industri, perdagangan maupun jasa (Bonde $\mathrm{R}$ A, 2015). Seiring berkembangnya teknologi informasi, maka perlu diterapkan suatu strategi yang lebih baik dengan cara mengimplementasikan suatu produk teknologi komunikasi informasi yang dapat membantu suatu usaha menjadi lebih efektif dalam meningkatkan penghasilan usaha, serta dapat menunjang dalam pengambilan keputusan yang lebih baik bagi pemilik usaha. Membuka usaha sendiri adalah hal yang patut dipertimbangkan untuk memperoleh penghasilan dalam menopang kebutuhan dan biaya hidup saat ini. Tentunya ada berbagai macam jenis usaha yang dapat dijadikan pilihan dalam mengembangkan usaha (Azmi,2013), salah satu hal yang menjanjikan adalah dalam bidang kuliner, dilihat dari kebutuhan dasar manusia, makanan adalah satu kebutuhan yang tidak akan di tinggalkan hingga kapanpun. Tidak seperti pakaian atau fashion yang seringkali berganti model sehingga akan berubah dan berangsur-angsur di tinggalkan. Makanan akan selalu di butuhkan selama makhluk hidup khususnya manusia masih hidup di dunia ini, namun saat sekarang ini makanan bukan hanya sekedar untuk memenuhi kebutuhan hidup saja, tapi sudah menjadi ladang bisnis bagi pelaku usaha, demi persaingan usaha yang ketat, saat ini sudah banyak diciptakan makanan dengan berbagai macam variasi. Di kabupaten Karawang sendiri telah banyak tersedia berbagai macam makanan yang berbeda beda, namun masih terjadi ketidakmerataan dalam hal lokasi penjualan, hal ini terbukti ketika kita dapat menemukan banyaknya makanan sejenis dalam satu lokasi tertentu, namun dilokasi yang lain kita tidak dapat menemukan satu jenis makanan tersebut. lokasi inilah yang nantinya akan menjadi salah satu pertimbangan dalam menentukan lokasi dalam membuka usaha kuliner.
Saat sekarang ini untuk memilih lokasi yang strategis sangatlah tidak mudah, dibutuhkan lokasi yang tepat, strategis dan efisien agar usaha kuliner dapat diterima dengan mudah oleh konsumen, maka dari itu diperlukan suatu sistem yang dapat memperhitungkan segala kriteria yang mendukung dalam pengambilan keputusan.

Sistem pendukung keputusan (SPK) sebagai sebuah sistem berbasis komputer yang membantu dalam proses pengambilan keputusan. SPK dirancang sedemikian rupa untuk membantu mendukung keputusan keputusan yang melibatkan masalahmasalah kompleks yang diformulasikan sebagai proble- problem semi terstruktur (Sebayang F.T, 2014). Tujuan sistem pendukung keputusan dalam pengambilan keputusan menggantikan manajer melainkan alat yang mendukung pembuat keputusan dalam mengambil keputusan (Fuspita dkk,2014). Sistem pendukung keputusan sebagai sistem informasi berbasis komputer yang adaptif, interaktif, fleksibel, yang secara khusus dikembangkan untuk mendukung solusi dari permasalahan manajemen yang tidak terstruktur untuk meningkatkan kualitas pengambilan keputusan (Azmi,2013). Metode yang dipakai dalam pengambilan keputusan untuk menentukan lokasi usaha kuliner ini adalah dengan metode naive bayes, metode naive bayes merupakan salah satu algoritma yang terdapat pada teknik klasifikasi. Naive Bayes merupakan pengklasifikasian dengan metode probabilitas dan statistik yang dikemukakan oleh ilmuwan Inggris Thomas Bayes, yaitu memprediksi peluang di masa depan berdasarkan pengalaman dimasa sebelumnya sehingga dikenal sebagai Teorema Bayes. Teorema tersebut dikombinasikan dengan naive dimana diasumsikan kondisi antar atribut saling bebas. Klasifikasi naive bayes diasumsikan bahwa ada atau tidak ciri tertentu dari sebuah kelas tidak ada hubungannya dengan ciri dari kelas lainnya (Bustami). Metode naive bayes memiliki tingkat akurasi yang cukup tinggi dan mudah dalam pemrograman.

Dengan adanya sistem pendukung keputusan dalam menentukan lokasi usaha kuliner yang strategis menggunakan metode naive bayes ini, bertujuan untuk 
mempermudah pengambilan keputusan untuk menentukan lokasi usaha kuliner yang strategis yang akan dijadikan untuk membuka tempat usaha.

\section{METODE PENELITIAN}

\section{Metode Pengembangan Sistem}

Metode pengembangan sisetem pada sistem penunjang keputusan menentukan lokasi usaha kuliner yang strategis, penulis menerapkan metode SDLC model Waterfall

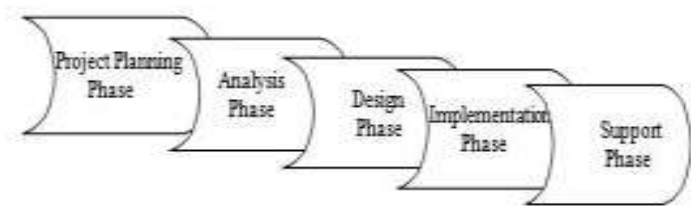

Gambar 1 System Development Live Cycle

\section{Project Planning phase}

Project planning phase atau fase perencanaan ini kami membuat beberapa perencanaan yang akan menjadi panduan kami dalam menyelesaikan proyek, yaitu :

1. Penentuan tempat atau lokasi penelitian. Kami melakukan penelitian di tempat tempat di kabupaten Karawang.

2. Pengumpulan data.

Pengumpulan data yang kami lakukan adalah :
a. Observasi.
b. Wawancara.
c. Pengumpulan berkas-berkas.
d. Pengumpulan jurnal-jurnal dan buku.

3. Identifikasi masalah.

Menemukan masalah yang ada di lapangan sehingga bisa memberikan penyelesaian yang tepat sesuai dengan masalah yang ditemukan di lokasi penelitian. Masalah yang kami temukan tersebut adalah sulitnya para pelaku usaha dalam menentukan sebuah lokasi yang strategis untuk membuka sebuah usaha

4. Perencanaan waktu.

Membuat perencanaan waktu sehingga proyek dapat diselesaikan tepat waktu sesuai dengan target.

5. Penentuan metode.

Menentukan metode penelitian yang tepat, kami mengambil metode SDLC dengan model waterfall.

6. Penentuan media.

7. Menentukan aplikasi apa yang tepat untuk kami bangun dan kami terapkan sehingga dapat menyelesaikan masalah yang ada, serta menentukan perangkat keras apa saja yang dibutuhkan untuk mendukung aplikasi yang akan kami bangun.

\section{Analysis Phase}

Tahapan analisis merupakan tahapan melakukan pengambilan data-data yang ada di lapangan penelitian untuk dijadikan bahan pengembangan sistem yang baru, adapun beberapa langkah-langkah yang kami lakukan, yaitu :

1. Observasi serta melihat sistem yang berjalan

2. Wawancara.

3. Pengumpulan berkas-berkas.

4. Studi literatur.

Pada tahapan analisis ini juga kami membuat sebuah prosedur sistem berjalan yang ada di lapangan dan juga prosedur sistem ajuan sebagai perbaikan sistem dengan menggunakan berbagai langkah, meliputi flowmap, flowchart, diagram contex dan DFD.

\section{Design Phase}

Tahapan desain terdapat berbagai desain yang akan disesuaikan dengan sistem yang diajukan sebagai perbaikan dari sistem yang sedang berjalan di lapangan penelitian. Desain yang kami persiapkan yaitu desain database dan desain antar muka, pada desain database kami membuat sebuah rancangan table yang kemudian pada tiap-tiap table tersebut dihubungkan dengan relasi antar table yang pada akhirnya membentuk sebuah sistem yang akan menjadi pendukung perangkat lunak pada desain antarmuka. Rancangan desain antarmuka dibuat mulai dari desain antarmuka masukan, antarmuka proses dan juga antarmuka keluaran sehingga menjadi satu kesatuan antara rancangan database dengan rancangan antarmuka.

\section{Implementation phase}

Fase implementasi merupakan tahapan uji coba dari sistem ajuan yang sudah kami 
rancang dan kami terapkan pada program yang sudah kami buat, pengujian aplikasi yang kami buat dengan dua cara pengujian yaitu dengan black box dan white box.

Pengujian black box ini kami melakukan uji coba pada user yaitu pada pelaku usaha kuliner dan hasil dari pengujian ini akan dijadikan masukan untuk perbaikan sistem yang kami buat.

Pengujian white box ini kami melakukan uji coba source code atau kode-kode program dengan yang dilakukan oleh pihak yang independen untuk mengetahui dan menganalisis adanya kesalahan atau tidak dengan modul-modul program yang sudah kami buat.

\section{Analisis Perhitungan Naive Bayes}

Sistem pendukung keputusan menentukkan lokasi usaha kuliner yang strategis menggunakan metode naive bayes. Menurut Yusnita dan Handini (2012), Metode naive bayes merupakan pendekatan statistik untuk melakukan inferensi induksi pada persoalan klasifikasi. Metode ini menggunakan probabilitas bersyarat sebagai dasarnya. Dalam ilmu statistik, probabilitas bersyarat dinyatakan Probabilitas $X$ didalam $\mathrm{Y}$ adalah probabilitas interaksi $\mathrm{X}$ dan $\mathrm{Y}$ dari probabilitas $\mathrm{Y}$, atau dengan bahasa lain $\mathrm{P}(\mathrm{X} \mid \mathrm{Y})$ adalah prosentase banyaknya $\mathrm{X}$ didalam Y.

Naive Bayes menurut Trias (2010) adalah salah satu penerapan theorema Bayes dalam klasifikasi, Naive Bayes didasarkan pada asumsi penyederhanaan bahwa nilai atribut secara kondisional saling bebas jika diberikan nilai output. Algoritme bayes mempelajari kejadian- kejadian dari rekaman database dengan cara memperhitungkan korelasi antara variabel yang dianalisis dengan variabel-variabel lainnya. Hasilnya adalah kita dapat memprediksi sesuatu, misalnya apakah seseorang berasal dari golongan tertentu berdasarkan variabel- variabel yang melekat padanya. Selain itu, naive bayes dapat juga menganalisis variabel-variabel yang paling mempengaruhinya dalam bentuk peluang.

Menurut Natalius (2010), pada teorema bayes bila terdapat dua kejadian yang terpisah (misalkan A dan B), maka teorema bayes dirumuskan sebagai berikut:

Prosterior $=\mathrm{P}(\mathrm{A} \mid \mathrm{B})={ }^{P(A)} \mathrm{P}(\mathrm{B} \mid \mathrm{A}) \mathrm{P}(\mathrm{B})$

Untuk menjelaskan teorema naive bayes, perlu diketahui bahwa proses klasifikasi memerlukan sejumlah petunjuk untuk menentukan kelas apa yang cocok bagi contoh yang dianalisis tersebut. Karena itu, teorema bayes di atas disesuaikan sebagai berikut:

$P(C \mid F 1, \ldots, F n)=\underline{P C A P() F, \ldots . F n \mid C,)}$

$P(\mathrm{~F} 1, \ldots, \mathrm{Fn})$

Dimana variabel $\mathrm{C}$ merepresentasikan kelas, sementara variabel F1 ... Fn merepresentasikan karakteristikkarakteristik petunjuk yang dibutuhkan untuk melakukan klasifikasi. Maka rumus tersebut menjelaskan bahwa peluang masuknya sampel dengan karakteristik tertentu dalam kelas C (posterior) adalah peluang munculnya kelas C (sebelum masuknya sampel tersebut, seringkali disebut prior), dikali dengan peluang kemunculan karakteristikkarakteristik sampel pada kelas C (disebut juga likelihood), dibagi dengan peluang kemunculan karakteristikkarakteristik sampel secara global (disebut juga evidence). Karena itu, dapat pula ditulis secara sederhana sebagai berikut:

Posterior $=$ prior *lkehood

\section{Evidence}

Nilai evidence selalu tetap untuk setiap kelas pada satu sampel. Nilai dari Posterior tersebut yang nantinya akan dibandingkan dengan nilai-nilai Posterior kelas lainnya untuk menentukan ke kelas apa suatu sampel akan diklasifikasikan

Kriteria yang digunakan untuk menentukan lokasi usaha kuliner yang strategis menggunakan naive bayes adalah sebagai berikut:

1.Dekat dengan pusat kota/pusat keramaian

a. Dekat (dibawah 50 meter)

b. Jauh (diatas 50 meter)

2.Mempunyai trafik yag tinggi
a. Tinggi
b. Sedang
c. Rendah

3.Kebersihan (Ligkungan yang bersih, jauh dari lokasi pembuangan sampah)
a. Bersih

b. Sedang 
c. Kumuh

4 Keamanan yang terjamin
a. Aman
b. Kurang aman
c. Tidak aman

5. Harga sewa lokasi
a. Murah (dibawah 1 juta)
b. Sedang (antara 1 juta sampai 10 juta)
c. Mahal (diatas 10 juta)

6.Kelengkapan usaha (seperti air listrik,lahan parkir)
a. Sangat lengkap
b. Lengkap
c. Kurang lengkap

7. Jumlah usaha/pesaing yang berjualan didaerah tersebut
a. Bayak (lebih dari 3)
b. Sedikit (kurang dari 3)

8. Potensi perkembangan lokasi untuk kedepannya
a. Sangat meunjang
b. Menunjang
c. Tidak menunjang

9.Legalitas lokasi usaha (perijinan)
a. Legal
b. ilegal

10. Dekat dengan bahan baku dan bahan penunjang

a. Dekat (kurang dari 50 meter)

b. Jauh (lebih dari 50 meter)

\section{Prosedur Naive Bayes Dalam Menentukan Lokasi Usaha Kuliner Yanng Strategis}

Sesuai dengan langkah-langkah yang ada, proses perhitungan dan keluaran yang diberikan untuk penelitian dalam menentukan lokasi yang strategis ini adalah :

a. Menentukkan jenis-jenis kriteria apa saja yang digunakan dalam melakukan perhitungan naive bayes karena kriteria akan menjadi persyaratan utama dalam menentukkan lokasi yang strategis.

b. Menyiapkan kriteria yang digunakan untuk melakukan proses perhitungan naive bayes.

c. Menyusun kriteria-kriteria tersebut dalam bentuk tabel aturan.

d. Membuat tabel kemunculan setiap nilai untuk atribut dari setiap kriteria.

e. Menghitung nilai likehood ya dan likehood tidak, dimana dari hasil akhir nilai tersebut digunakan untuk menghitung nilai probabilitas.

f. Menghitung nilai probabilitas, dapat dihitung dengan melakukan normalisasi terhadap nilai likehood dimana nilai yang paling besar itulah yang dianggap strategis atau kurang strategis.

\section{Perhitungan Naive Bayes}

Tahap awal cara kerja dari perhitungan naive bayes adalah dengan melakukan pengambilan data dari beberapa lokasi baik yang strategis ataupun tidak strategis. Dari data yang sudah tersedia, maka lakukan perhitungan dengan langkah sebagai berikut:

1. Menghitung jumlah class/label

2. Menghitug dengan kasus yag sama dengan class yang sama

3. Kalikan semua hasil variabel strategis dan tidak strategis

4. Bandingkan hasil class strategis dan tidak strategis

5. Nilai yang memiliki probabilitas tertinggi merupakan hasil nya.

\section{Analisis Sistem}

\section{Prosedur Sistem Ajuan}

Adapun sistem ajuan sistem penunjang keputusan menentukan lokasi usaha kuliner yang strategis adalah sebagai berikut :

1. Admin masuk kedalam sistem dengan login terlebih dahulu dan melalui proses verifikasi, apabila gagal admin kembali pada form login dan apabila sukses admin masuk dalam sistem.

2. Admin masuk kedalam menu kriteria dan mengedit kriteria dan menyimpan dalam database.

3. Admin masuk ke dalam menu kriteria dan mengedit sub kriteria dan menyimpan dalam database.

4. Admin masuk ke dalam menu tabel aturan dan menginput data aturan dan menyimpan dalam database.

5. Admin masuk ke dalam menu nilai atribut dan sistem mengambil data dari database kemudian menampilkannya.

6. Admin masuk ke dalam menu list hasil input dan sistem mengambil data dari database kemudian 
menampilkannya.

7. User masuk ke dalan menu proses menentukan lokasi.

8. User mengisi form identitas diri yang disediakan sistem, dan sistem menyimpan dalam database.

9. User mengisi kriteria penentu yang disediakan sistem dan sistem menyimpan dalam database.

10. Sistem menerima dan memproses kriteria yang di input dengan naïve bayes dan menyimpan hasil kedalam database.

11. Sistem menampilkan hasil yang diminta oleh user.

\section{Flow Map}

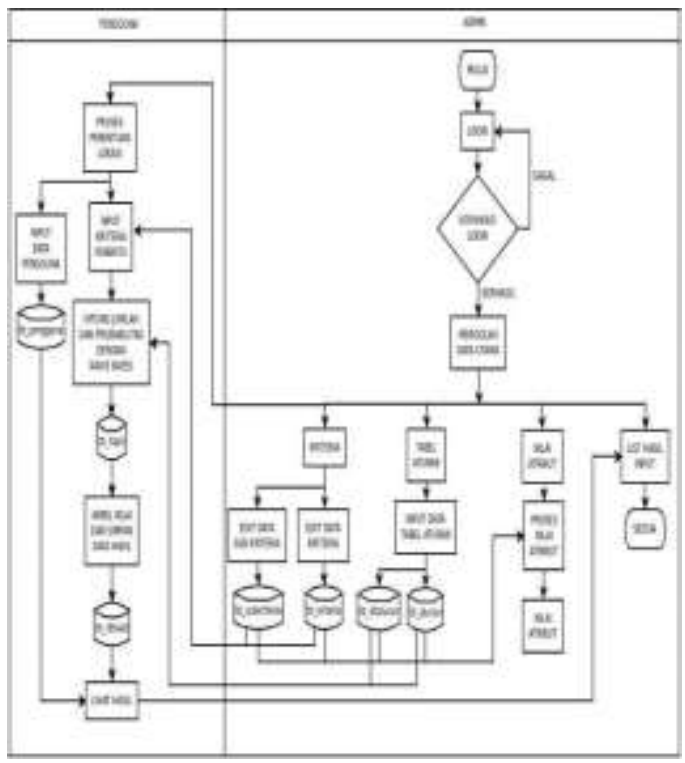

Gambar 2 Flow Map

\section{Struktur Proses}

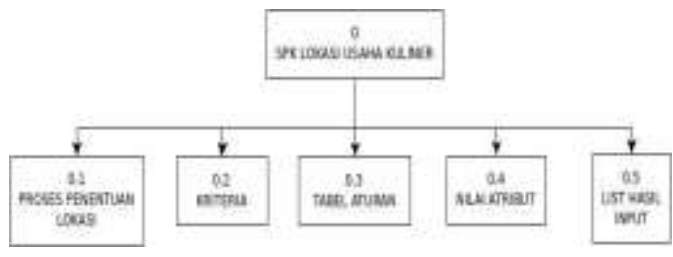

Gambar 3 Sruktur Proses

\section{Diagram Context}

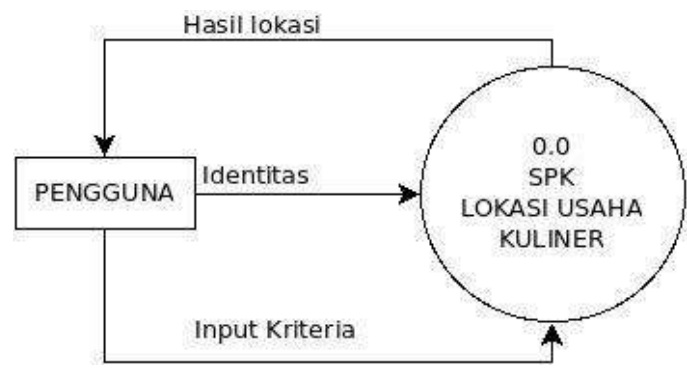

Gambar 4 Diagram Context

\section{DFD logic level 0.0}

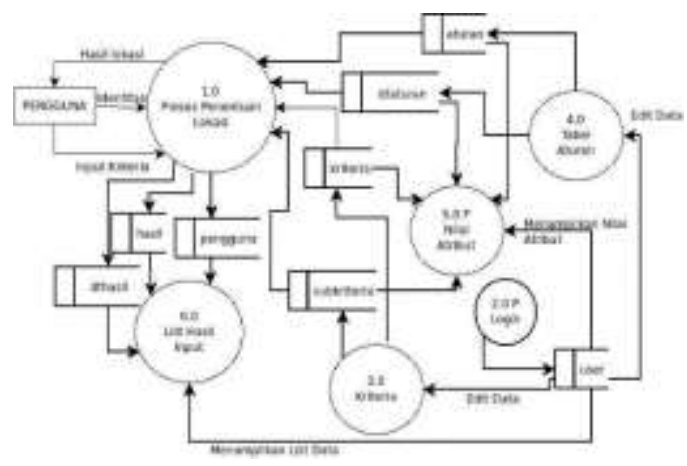

Gambar 5 DFD logic level 0.0

\section{HASIL DAN PEMBAHASAN}

Pada tahap implementasi sistem, rancangan dan desain sistem diimplementasikan dengan bahasa pemrograman php dan database MySql.

Berikut adalah flow chart proses menentukan lokasi usaha kuliner yang strategis menggunakan metode naive bayes di awali dengan memilih menu proses penentuan kriteria, kemudian user mengisi kriteria yang telah disediakan, setelah itu dilakukan proses perhitungan likehood ya dan likehood tidak, dari nilai hasil akhir likehood ya dan likehood tidak dilanjutkan dengan perhitungan probabilitas ya dan likehood tidak, jika nilai probabilitas ya lebih tinggi dari probabilitas tidak maka lokasi strategis, sebaliknya jika nilai probabilitas tidak lebih tinggi dari probabilitasnya maka hasilnya adalah tidak strategis. 


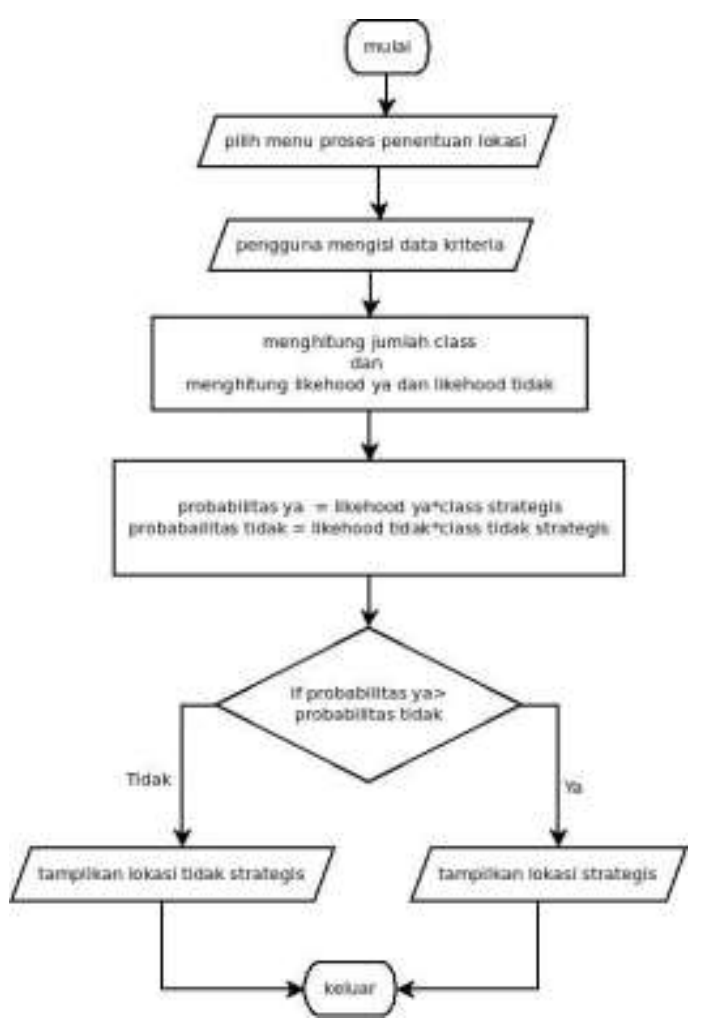

Gambar 6 Flowchart

Berdasarkan flowchart di atas maka akan di jabarkan pada tabel dibawah ini :

Tabel 1 Tahapan Proses

\begin{tabular}{|l|l|l|}
\hline No & Tahapan & Deskripsi \\
\hline 1 & $\begin{array}{l}\text { Pilih menu proses } \\
\text { penentuan lokasi }\end{array}$ & $\begin{array}{l}\text { Untuk memilih } \\
\text { menu proses } \\
\text { penentuan lokasi } \\
\text { sehingga bisa } \\
\text { dilakukan } \\
\text { perhitungan }\end{array}$ \\
\hline 2 & $\begin{array}{l}\text { Pengguna } \\
\text { mengisi data } \\
\text { kriteria }\end{array}$ & $\begin{array}{l}\text { Untuk mengisi data } \\
\text { kriteria yang sudah } \\
\text { ditentukan }\end{array}$ \\
\hline 3 & $\begin{array}{l}\text { Perhitungan naive } \\
\text { bayes Likehood } \\
\text { ya likehood } \\
\text { tidak = }\end{array}$ & $\begin{array}{l}\text { Perhitungan } \\
\text { naive bayes } \\
\text { merupakan } \\
\text { perhitungan yang } \\
\text { dipakai dalam } \\
\text { menentukan } \\
\text { lokasi yang } \\
\text { strategis ini yaitu } \\
\text { dengan } \\
\text { menghitung nilai } \\
\text { dari likehood ya } \\
\text { dan likehood } \\
\text { tidak }\end{array}$ \\
\hline 4 & Probabilitas ya $=$ & $\begin{array}{l}\text { Menghitung nilai } \\
\text { probabilitas yaitu }\end{array}$ \\
\hline
\end{tabular}

\begin{tabular}{|l|l|l|}
\hline & $\begin{array}{l}\text { probabilitas tidak } \\
=\end{array}$ & $\begin{array}{l}\text { dengan melakukan } \\
\text { normalisasi nilai } \\
\text { terhadap dimana } \\
\text { likehood dima paling } \\
\text { nilai yang } \\
\text { besar itulah yang } \\
\text { dianggap strategis } \\
\text { atau tidak strategis. }\end{array}$ \\
\hline 5 & $\begin{array}{l}\text { Tampilkan lokasi } \\
\text { tidak strategis }\end{array}$ & $\begin{array}{l}\text { Jika nilai } \\
\text { probabilitas } \\
\text { tidak, lebih besar } \\
\text { dari probabilitas } \\
\text { ya, a, akan tampil } \\
\text { maka akan } \\
\text { "lokasi tidak } \\
\text { strategis }\end{array}$ \\
\hline 6 & $\begin{array}{l}\text { Tampilkan lokasi } \\
\text { strategis }\end{array}$ & $\begin{array}{l}\text { Jika nilai } \\
\text { probabilitas ya, } \\
\text { lebih besar dari } \\
\text { probabilitas tidak, } \\
\text { maka akan tampil } \\
\text { lokasi strategis }\end{array}$ \\
\hline
\end{tabular}

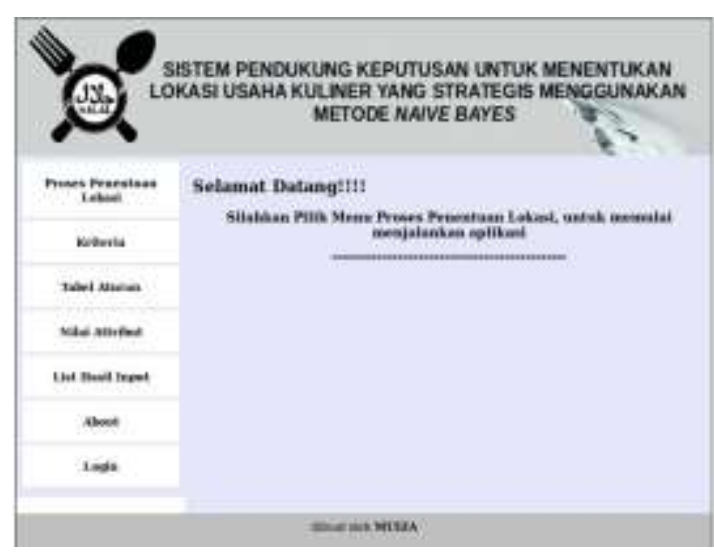

Gambar 7 Menu Utama

Proses Penentuan Lokasi

Data Pengguna

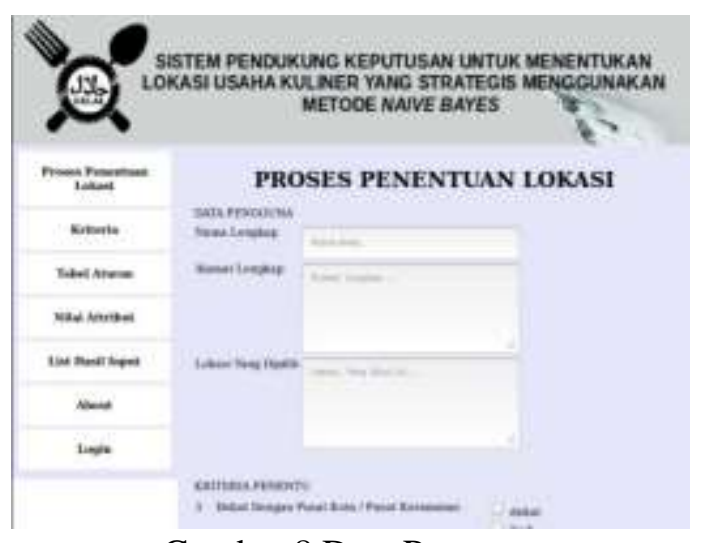

Gambar 8 Data Pengguna 


\section{Kriteria Penentu}

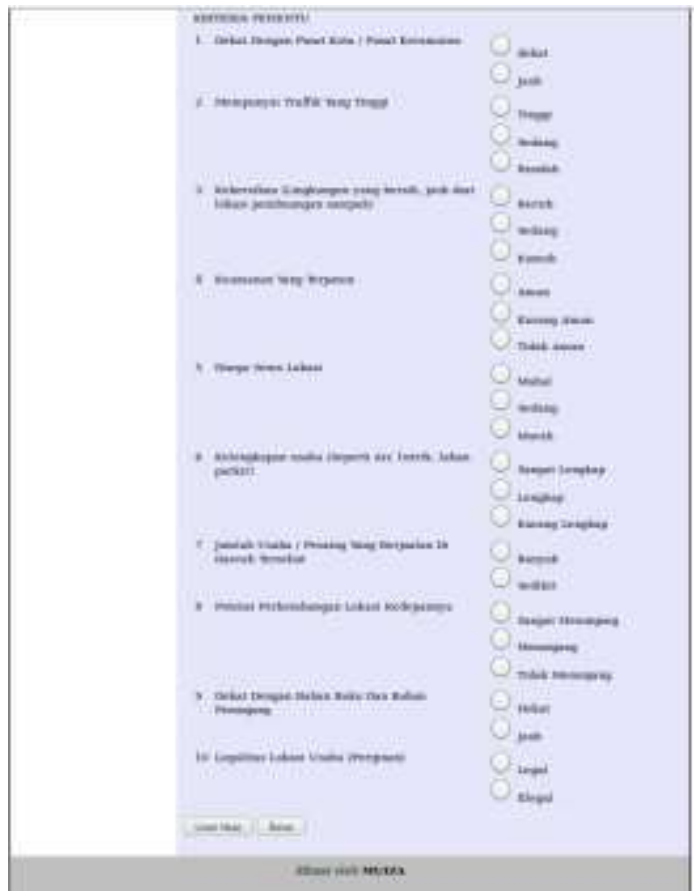

Gambar 9 Kriteria Penentu

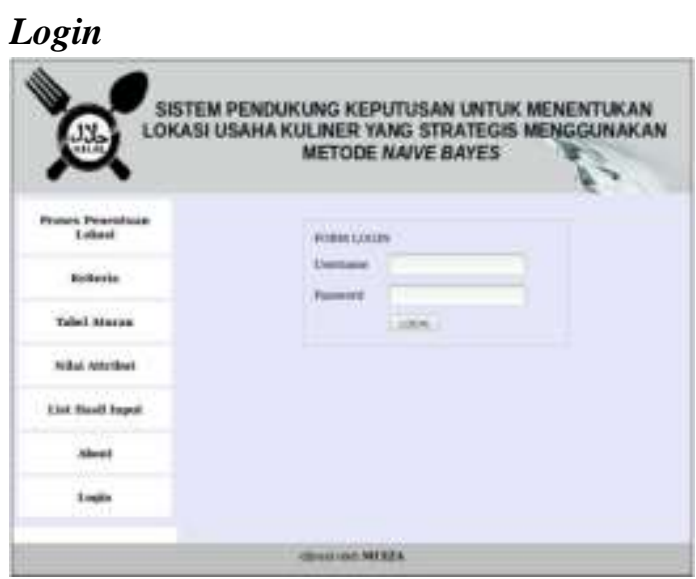

Kriteria

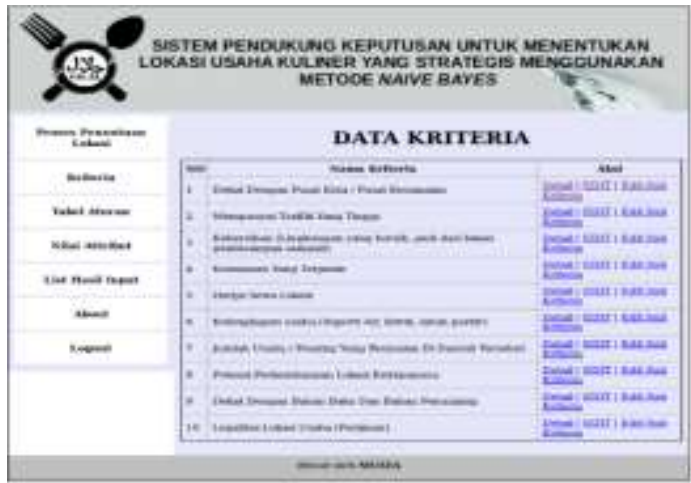

Gambar 11 Form Input Kriteria
Nilai Atribut

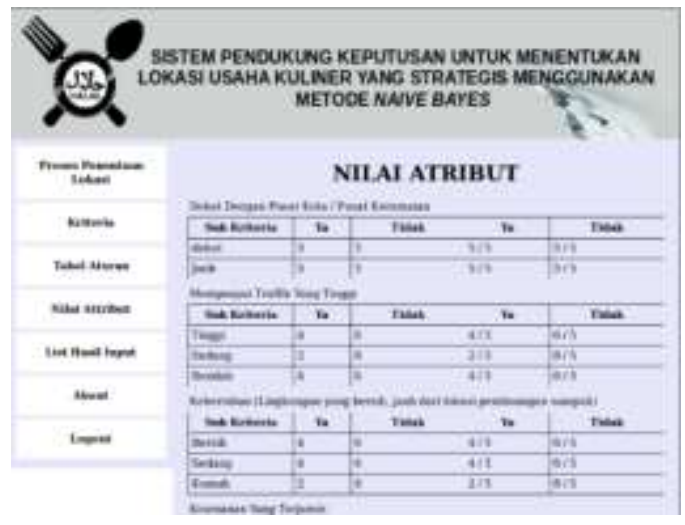

Gambar 12 Tabel Atribut

List Hasil Input

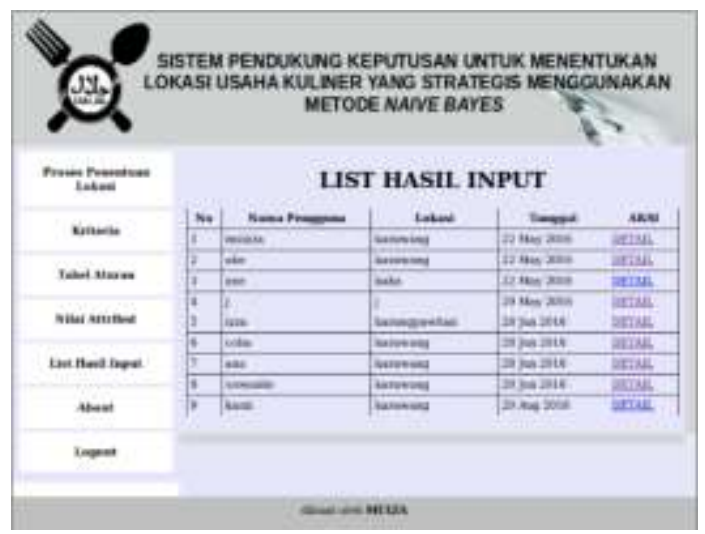

Gambar 13 List Hasil

\section{KESIMPULAN DAN SARAN}

\section{Kesimpulan}

Berdasarkan uraian di atas, penulis dapat mengambil sejumlah kesimpulan, sebagai berikut:

1. Sistem yang dibangun untuk menentukan lokasi usaha kuliner yang strategis ini dapat digunakan oleh para pelaku usaha dalam mengambil keputusan untuk menentukan sebuah lokasi .

2. Sistem Penunjang Keputusan yang dibangun ini dapat mempercepat proses penentuan lokasi usaha, karena proses ini dilakukan secara otomatis. Dimana pengguna hanya mengisi data kriteria pada form yang disediakan dan selanjutnya data akan diproses 
menggunakan metode naive bayes sehingga didapatkan hasil dari sistem tersebut yaitu strategis ataupun tidak strategis.

3. Sistem pendukung keputusan ini dipergunakan sebagai "second opinion" atau "information sources" yang dapat dipakai sebagai bahan pertimbangan sebelum seorang memutuskan untuk mengambil suatu keputusan.

4. Sistem pendukung keputusan ini menggunakan naive bayes yaitu dapat memprediksi peluang di masa depan berdasarkan pengalaman dimasa sebelumnya.

5. Dalam sistem pendukung keputusan ini, hanya menggunakan 10 aturan dan 10 kriteria saja.

\section{Saran}

Berdasarkan hasil simpulan diatas, maka sistem penunjang keputusan ini dapat dikembangkan kembali sebagai berikut :

1. Sistem penunjang keputusan ini terbatas hanya usaha kuliner saja, sehingga kedepannya dapat dikembangkan untuk usaha yang lain nya.

2. Sistem penunjang ini dapat dikembangkan dengan menggunakan metode metode yang lain.

\section{DAFTAR PUSTAKA}

Azmi M. 2013. Sistem Pendukung Keputusan Untuk Memilih Usahan Waralaba Makanan Menggunakan Metode Topsis. Jurnal Elektron. Vol 5. No 2 Edisi Desember 2013. Padang.

Bonde R A. 2015. Analisis Biaya Diferensial

Dalam Pengambilan Keputusan Memproduksi Sendiri Atau Membeli Bahan Baku Pada RM. Bakso Ba'nyuk Nyang Manado. Jurnal EMBA. Vol 3. No 1Maret 2015. ISSN 2303-1174. Manado.

Bustami. 2014. Penerapan Algoritma Naive Bayes Untuk Mengklasifikasi Data Nasabah Asuransi. Jurnal Rekursif. Vol 2 No 1 Maret 2014. ISSN 23030755 .

Muchtar J. 2009. Penentuan Jalur Efektif
Pola Data Flow Diagram (DFD) dengan Metode Structural Equation Modeling (SEM) di PT. Anugrah Kurnia Pusaka, Medan.

Hall, J.A. 2007. Accounting Information System.Jakarta.

Handiri R dan Yusnita A. 2012. Sistem Pendukung Keputusan Menentukan Lokasi Umah Makan Yang Strategis Menggunakan Metode Naive Bayes.

Karsono K.2013.

Website:http://kundang.weblog.esaun ggul.ac.id/2013/07/16/hak-

akses/(diakses tanggal 01 februari 2016).

Muchtar J. 2009. Penentuan Jalur Efektif Pola Data Flow Diagram (DFD) dengan Metode Structural Equation Modeling (SEM) di PT. Anugrah Kurnia Pusaka, Medan.

Nasution S. 2009. Sistem Informasi Pengolahan Data Gaji Pegawai Pada Kantor Dinas Perikanan Dan Kelautan Labuhan Batu Dengan Menggunakan Visual Basic 6.0, 2008, Halaman 41, Medan.

Nugroho, Bunafit. 2004. Aplikasi Pemrograman Web Dinamis dengan PHP dan MySQL, Gava Media, Yogyakarta.

Pamungkas O, Saputra R, Wirawan P W. Sistem Pendukung Keputusan Wisata Kuliner Berbasis Gis pada Perangkat Android.

Peranginangin, Kasiman 2006, Aplikasi Web dengan PHP dan Mysql, Yogyakarta.

Satzinger, dkk. 2007. System Analysis and Design in a Changing World, Fourth Edition, Thomson Course Technology, Cananda.

Sebayang F.T. 2014. Sistem Pendukung Keputusan Penentuan Lokasi Pameran Berdasarkan Peluang Pengunjung dengan Metode Bayes.

Trias R.2010. Naive Bayes, Website:https://rahmadya.com/2010/ 06/24/ix-naive- bayes/ (diakses tanggal 14 mei 2016).

Waturida, Iriano Pedro. 2012. Aplikasi Pembelian Material Proyek sebagai Pendukung Laporan Keuangan Menggunakan MYOB Acconting pada PT Biro Teknik Cahaya Kabupaten Cirebon, Halaman 22, Cirebon 
